Економічні науки: збірник наукових праць Луиького національного технічного університету. Серія "Регіональна економіка". Випуск 17 (67). Редкол.: відп. ред. к.е.н., професор І.В. Кривов'язюк. Луиьк: ІВВ Луцького НТУ, 2020. 348 с.

\author{
УДК 332.1 \\ Фесіна Ю.Г., к.е.н., доцент \\ Дзюбинська О.В., асистент \\ Луцький національний технічний університет
}

\title{
СОЦІАЛЬНЕ ПІДПРИЄМНИЦТВО У ФОРМУВАННІ КРУГОВОЇ МОДЕЛІ ПОВОДЖЕННЯ 3 ПОБУТОВИМИ ВІДХОДАМИ РЕГІОНУ
}

Тематика цього дослідження обумовлена появою нового тренду в сфері поводження з відходами - кругової моделі економіки. Якщо в Свропі та інших країнах світу вона виходить на стадію розвитку, то в Україні спостерігається період іiі обговорення та здійснення окремих перманентних спроб розпочати імплементацію такої моделі. Вона докорінно змінює уявлення про відходи в контексті їх асоціювання 3 власністю, яка вимагає відповідальності та ресурсом, який може приносити користь. Це вимагає зміни мислення суб' єктів у сфері поводження з відходами. Водночас регіональна економічна система не справляється 3 переробкою відходів. Тому вихід слід шукати в розвитку підприємницьких ініціатив насамперед тих, хто продукують відходи-ресурси. Якщо для відходів, які утворюються в сфері економічної діяльності це вирішується через інструмент соціальної відповідальності бізнесу, то для побутових відходів панацеєю може стати розвиток соціального підприємництва.

Ключові слова: відходи, побутові відходи, кругова економіка, соціальна відповідальність, соціальне підприємництво. 
Fesina Yu., Dziubynska O.

\section{SOCIAL ENTREPRENEURSHIP IN FORMING A CIRCULAR MODEL OF MUNICIPAL WASTE MANAGEMENT IN THE REGION}

The topic of this research is conditioned by the appearance of a new trend in waste management - the circular model of economy. If in Europe and other countries of the world it is entering the stage of development, then in Ukraine there is a period of discussion and implementation of individual permanent attempts to start implementation of such model. The model fundamentally changes the idea of waste. According to the model, waste is associated with property, which requires responsibility. Waste is also associated with resources that can be beneficial. It requires a fundamental change in the mindset of actors in waste management. At the same time, the regional economic system does not cope with waste management. Therefore, the solution should be sought in the development of entrepreneurial initiatives. First of all, this applies to those who promote waste generation. For wastes generated in the sphere of economic activity, this is solved through an instrument of business social responsibility. For domestic waste, in our opinion, the development of social entrepreneurship can be a panacea. This is important because regional authorities are not able to solve the problem of transition to the circular model alone. In the same way as businesses are not able to effectively deal with waste recycling or the use of secondary resources without initiatives of separate waste sorting by the population. Thus, waste is the subject of intersectoral cooperation between big business and social entrepreneurs. Social enterprises can play a role of outsourcing agents by supplying recyclable waste to recyclable enterprises. They can also choose the role of an independent player in waste recycling. In this case, the method of cooperation of social enterprises will be effective. The publication also discusses ways to use financial resources for social entrepreneurs.

Key words: waste, municipal waste, circular economy, social responsibility, social entrepreneurship.

\section{Фесина Ю.Г., Дзюбинская О.В. СОЦИАЛЬНОЕ ПРЕДПРИНИМАТЕЛЬСТВО В ФОРМИРОВАНИИ КРУГОВОЙ МОДЕЛИ ОБРАЩЕНИЯ С БЫТОВЫМИ ОТХОДАМИ РЕГИОНА}

Тематика этого исследования обусловлена появлением нового тренда в сфере обращения с отходами - круговой модели экономики. Если в Европе и других странах мира она выходит на стадию развития, то в Украине наблюдается период обсуждения и осуществления отдельных перманентных попыток начать имплементацию такой модели. Она в корне меняет 
Економічні науки: збірник наукових праць Луиького національного технічного університету. Серія "Регіональна економіка". Випуск 17 (67). Редкол.: відп. ред. к.е.н., професор І.В. Кривов'язюк. Луиьк: ІВВ Луцького НТУ, 2020. 348 с.

представление об отходах в контексте их ассоциирования с собственностью, которая требует ответственности и ресурсом, который может приносить пользу. Это требует изменения мышления субъектов в сфере обращения с отходами. В то же время региональная экономическая система не справляется с переработкой отходов. Поэтому выход следует искать в развитии предпринимательских инициатив в первую очередь тех, кто производят отходы-ресурсы. Если для отходов, которые образуются в сфере экономической деятельности это решается через инструмент социальной ответственности бизнеса, то для бытовых отходов панацеей может стать развитие социального предпринимательства.

Ключевые слова: отходы, твердые бытовые отходы, круговая экономика, социальная ответственность, социальное предпринимательство.

Постановка проблеми у загальному вигляді і її зв'язок 3 важливими науковими та практичними завданнями. В умовах постійного зростання споживчих настроїв збільшуються витрати ресурсів, природних в тому числі. Все це створює додаткове навантаження на регіональні економічні системи, які, як правило, виступають донорами таких ресурсів. За умови сповідування в подальшому лінійної бізнес-моделі, окремі ресурси будуть переходити в розряд дефіцитних, що посилюватиме їх цінову волатильність. Як відмічають окремі дослідники, лінійна модель створює проблему вилучення природного капіталу 3 навколишнього середовища та призводить до зменшення вартості природного капіталу через виникнення проблеми забруднення відходами [1, с. 371]. Тобто така модель позбавляє виробника відповідальної поведінки та прояву матеріального інтересу до відходів, як потенційних ресурсів для формування нової доданої вартості. Поява концепції сталого розвитку сприяла виникненню бізнес-моделі кругової економіки. На противагу лінійній моделі, планування майбутнього поступлення ресурсів тут здійснюється ще на стадії розробки нових продуктів. При цьому кожен компонент, 3 якого виготовляється продукт, немає перспектив стати повноцінним відходом, адже має заздалегідь визначену ресурсну роль у процесі повторного застосування, оновлення чи переробки. 
Економічні науки: збірник наукових праць Луиького національного технічного університету. Серія "Регіональна економіка". Випуск 17 (67). Редкол.: відп. ред. к.е.н., професор І.В. Кривов'язюк. Луиьк: ІВВ Луцького НТУ, 2020. 348 с.

Аналіз останніх досліджень, у яких започатковано вирішення проблеми. Британські дослідники Н. Міллар, Е. МакЛауглін та Т. Бюргер, досліджуючи квінтесенцію кругової економіки констатують, що вона досить часто розглядається як інструмент забезпечення сталого розвитку. Проте на сучасному етапі не до кінця зрозумілим є те, чи може кругова економіка сприяти економічному зростанню, одночасно виконуючи функцію захисту навколишнього середовища та забезпечення соціальної справедливості для теперішнього й майбутніх поколінь [2]. 3 їх аргументами можна погодитися 3 огляду на те, що модель кругової економіки нині перебуває лише на етапі впровадження, вона не до кінця адаптована й головним чином виробники не готові відмовитися від лінійної моделі господарювання.

Окремі автори стверджують, що модель кругової економіки забезпечує інтеграцію між сталим розвитком та розвитком бізнесу. Так, група міжнародних дослідників сфери державних послуг, яка базується на факультеті бізнесу Університету Грінвіч (Великобританія) вважає, що кругова економіка володіє широким потенціалом для створення робочих місць із-за того, що процеси повторного використання та переробки трудомісткі. Вона відкриває можливості для розвитку окремих бізнесових сегментів - переробка та оптова торгівля відходами, ремонт та роздрібна торівля вживаними товарами. Прогнозується, що в СС до 2030 р. в сфері кругової економіки може бути створено до 3 млн робочих місць. При цьому потенціал цей розподілений нерівномірно й основні переваги матимуть країни, які вже досить глибоко просунулися в питанні поводження з відходами й уже мають високу частку зайнятих у цій сфері (Німеччина, Великобританія, Іспанія, Італія, Франція). Однак, це не позбавляє шансів інших країн створювати робочі місця за рахунок кругової економіки [3, с. 23]. Аналогічно вважає вітчизняна дослідниця Н. Савченко, котра стверджує, що впровадження кругової економіки може забезпечити позитивний ефект для трансформації сфери зайнятості. Він, на думку науковиці, створюватиметься за рахунок подовження 
Економічні науки: збірник наукових праць Луиького національного технічного університету. Серія "Регіональна економіка". Випуск 17 (67). Редкол.: відп. ред. к.е.н., професор І.В. Кривов'язюк. Луиьк: ІВВ Луцького НТУ, 2020. 348 с.

терміну використання продукту на кожному етапі його експлуатації, а після його завершення - за рахунок створення нових робочих місць. При цьому сфера виробництва на засадах кругової економіки вимагатиме працівників інженерного фаху [4].

I. Зварич пропонує до традиційних принципів кругової економіки - скорочення (reduce) відходів, повторне використання (reuse) відходів, переробка (recycle) відходів, додати четвертий, який проявляється при формуванні глобальних циркулярних ланцюгів створення доданої вартості, соціальну відповідальність (responsibility) [5, с. 43-44]. Тут авторка веде мову про соціальну відповідальність зі сторони бізнесу, що в практиці кругової економіки та поводження 3 відходами звучить, як розширена відповідальність виробника. Проте поряд із цим слід вести мову про те, що відповідальність не може бути одностороння - лише для виробників благ. Адже 3 іншого боку присутні споживачі цих благ, які безпосередньо перетворюють їх у відходи. Тому слід вести мову й про відповідальність споживача. Й така відповідальність може бути встановлена за рахунок розвитку соціальних ініціатив на місцях, що досить легко можуть бути поставлені на платформу соціального підприємництва. Як справедливо відзначає С. Бойченко, соціальне підприємництво спрямоване саме на пом'якшення або вирішення соціальних проблем [6]. Якщо враховувати думку Н. Добрової про те, що соціальне підприємництво є системою господарювання, складовими якої $є$ соціальні підприємства, які орієнтовані на досягнення добробуту територіальних громад шляхом використання системного взаємозв' язку розвитку соціального підприємництва і розвитку місцевої економіки [7], то справедливо буде вважати, що соціальне підприємництво в секторі поводження з відходами дозволяє покращити соціально-економічний потенціал регіонів. Як відмічають О. Чуйко та В. Шкуро, соціальні підприємства за видами еколого-орієнтованої діяльності, можуть поділятися на чотири групи: підприємства, які займаються ресурсозбереженням (збір, сортування та переробка відходів); 
Економічні науки: збірник наукових праць Луиького національного технічного університету. Серія "Регіональна економіка". Випуск 17 (67). Редкол.: відп. ред. к.е.н., професор І.В. Кривов'язюк. Луиьк: ІВВ Луцького НТУ, 2020. 348 с.

підприємства, що розвивають екологічну культуру; підприємства, які займаються питаннями енергоефективності та підприємства, які здійснюють виробництво продуктів та надання послуг [8, с. 77]. Така диверсифікація діяльності свідчить про те, що соціальні підприємства здійснюють вплив на рівень свідомості населення, виробляють моделі поведінки і споживання, впроваджують інноваційні технології і рішення.

Цілі статті. У контексті необхідності імплементації моделі кругової економіки в сферу поводження 3 побутовими відходами метою поточного дослідження є експрес-аналіз стану накопичення відходів у регіональному розрізі та вивчення можливості використання інструменту соціального підприємництва для реалізації моделі.

Виклад основного матеріалу дослідження 3 повним обгрунтуванням отриманих наукових результатів. На основі опрацьованих нами статистичних даних про утворення відходів у розрізі джерел їх генерування, найбільше відходів утворюється в сферах економічної діяльності [8-9]. В 2018 р. у Тернопільській, Вінницькій, Херсонській, Івано-Франківській, Львівській, Миколаївський, Сумській, Запорізькій, Полтавській, Донецькій, Кіровоградській, Дніпропетровській областях на частку відходів від економічної діяльності в загальному обсязі відходів припадало від 90,5 \% до 99,8 \%. Найбільша частка відходів домогосподарств у структурі всіх отримуваних відходів спостерігалася в Закарпатській області - 74,7 \%, Одеській області - 56 \% та Київській області - $47 \%$. За період 2016-2018 pр. у розрізі окремих регіонів країни сталися відчутні зміни структури джерел утворення відходів. Так, у Волинській області в 2018 р. у порівнянні з 2016 р. відходи від економічної діяльності зросли на 18,7 \%, в Одеській області - на $10 \%$, у Сумській області - на $6 \%$. За цей же період частка відходів домогосподарств суттєво зросла в Київській (на $18 \%$ ), та Луганській областях (на 13,8 \%). Зазначимо, що в середньому по країнах ЄС $92 \%$ відходів утворюється в сфері економічної діяльності, а $8 \%$ - у домогосподарствах [11]. Незважаючи на низьку питому вагу побутових відходів у загальній величині 
Економічні науки: збірник наукових праџь Луцьького національного технічного університету. Серія "Регіональна економіка". Випуск 17 (67). Редкол.: відп. ред. к.е.н., професор І.В. Кривов'язюк. Луиьк: ІВВ Луцького НТУ, 2020. 348 с.

відходів, саме вони є найбільш складнішими для імплементації кругової моделі, оскільки існує багато джерел їх генерування, які розрізнені, а самі відходи є досить диверсифікованими.

У середньому в Свропейському Союзі в розрахунку на душу населення в 2018 р. припадало 492 кг відходів, що на 2 кг більше, ніж у 2017 р. та на 26 кг менше, ніж у 2008 р. Найбільший обсяг муніципальних відходів на душу населення в 2018 р. становив у Данії - 766 кг, найменший в Румунії - 272 кг [12]. В Україні за період 2015-2019 pр. середній обсяг побутових відходів на душу населення найвищий в Одеській області (понад 550 кг), Кіровоградській області (375 кг) та Київській області (315 кг) [13-19]. Нами було згруповано регіони держави за критерієм доходів населення для визначення їх впливу на обсяги придбання товарів і послуг та обсяги відходів домогосподарств (табл. 1).

Таблиця 1

Вплив доходів населення на обсяги споживання товарів і послуг та обсяги відходів домогосподарств у 2018 р.

\begin{tabular}{|c|c|c|c|c|c|}
\hline \multirow{2}{*}{$\begin{array}{c}\text { Групи регіонів } \\
\text { за } \\
\text { середньорічни } \\
\text { м доходом на } \\
\text { душу } \\
\text { населення, грн. }\end{array}$} & \multirow{2}{*}{$\begin{array}{c}\text { К-сть } \\
\text { регіонів } \\
\text { У групі }\end{array}$} & \multirow{2}{*}{$\begin{array}{c}\text { Середні } \\
\text { й дохід } \\
\text { за рік, } \\
\text { грн. }\end{array}$} & \multirow{2}{*}{$\begin{array}{c}\text { Середній } \\
\text { річний } \\
\text { обсяг } \\
\text { придбаних } \\
\text { товарів і } \\
\text { послуг, грн. }\end{array}$} & \multicolumn{2}{|c|}{$\begin{array}{l}\text { Середньорічний } \\
\text { обсяг відходів, кг }\end{array}$} \\
\hline & & & & $\begin{array}{c}\text { на } \\
\text { особу }\end{array}$ & $\begin{array}{c}\text { на } \\
\text { домогоспод. }\end{array}$ \\
\hline $\begin{array}{l}\text { I - від } 27363 \text { до } \\
50244\end{array}$ & 2 & 34658 & 20530 & 99,5 & 229,0 \\
\hline $\begin{array}{l}\text { II - від } 50245 \\
\text { до } 73126\end{array}$ & 12 & 65213 & 62199 & 119,5 & 320,4 \\
\hline $\begin{array}{l}\text { III - від } 73127 \\
\text { до } 96008\end{array}$ & 10 & 96007 & 74513 & 162,6 & 385,4 \\
\hline
\end{tabular}

Всі регіони країни було розділено на три групи за рівнем доходів населення. Так, до першої групи потрапило два регіони - Донецька та Луганська області. До другої групи потрапило 12 регіонів: Волинська, Житомирська, Закарпатська, ІваноФранківська, Кіровоградська, Миколаївська, Рівненська, Херсонська, Хмельницька, Черкаська, Чернівецька та Чернігівська області. До третьої групи потрапили Вінницька, 
Економічні науки: збірник наукових праць Луиького національного технічного університету. Серія "Регіональна економіка". Випуск 17 (67). Редкол.: відп. ред. к.е.н., професор І.В. Кривов'язюк. Луиьк: ІВВ Луцького НТУ, 2020. 348 с.

Дніпропетровська, Запорізька, Київська, Львівська, Одеська, Полтавська, Сумська, Тернопільська, Харківська області. Слід відмітити, що зі зростанням середньорічного доходу однієї особи, збільшуються й витрати на придбання товарів і послуг, а також зростають відходи як однієї особи, так i домогосподарства в цілому. Це ще раз підкреслює необхідність розгляду поняття відповідальності споживача в сфері поводження з відходами.

Первинною необхідністю використання соціального підприємництва в сфері поводження 3 відходами може слугувати той факт, що на відміну від класичного підприємництва, його головною метою виступають соціально ціннісні зміни у суспільстві. Тому соціальне підприємництво цілком вписується в сучасну парадигму інклюзивного сталого зростання. Останнє передбачає збільшення ступінь участі членів територіальної громади в соціально-економічних процесах, що відбуваються регіоні в тому числі й в питаннях поводження 3 відходами. Для того, щоб інститут соціального підприємництва став дієвим інструментом імплементації моделі кругової економіки та регіонального розвитку в цілому, потрібна наявність ряду умов: інституційна підтримка соціального підприємництва; популяризація культури соціального підприємництва загалом та в сфері поводження 3 відходами зокрема; розвиток підприємницьких навиків та соціальнопідприємницького потенціалу; забезпечення доступу до товарних ринків та фінансового ринку зокрема.

В СС інституційна платформа підтримки соціального підприємництва представлена як національними регуляторними рамками, так і загальноєвропейськими правилами. Наприклад, у В. Британії в 2002 р. було прийнято стратегію соціальних підприємств, у Словенії - стратегію соціального підприємництва (2013р.), у Данії - національну стратегію соціальних підприємств (2014 р.), Хорватії - стратегію розвитку соціального підприємництва (2015 р.), Швеції - стратегію соціальних підприємств та соціальних інновацій (2018р.), на Кіпрі - національний план дій для розвитку екосистеми 
Економічні науки: збірник наукових праць Луиького національного технічного університету. Серія "Регіональна економіка". Випуск 17 (67). Редкол.: відп. ред. к.е.н., професор І.В. Кривов'язюк. Луиьк: ІВВ Луцького НТУ, 2020. 348 с.

соціальних підприємств (2018р.), в Ірландії - національну політику щодо соціальних підприємств (2019 р.), у Польщі національну програму розвитку соціальної економіки (2019 р.) i т.д. У 2011 р. на всеєвропейському просторі Єврокомісією було ухвалено довгострокову програму «ніціатива соціального підприємництва» задля стимулювання країн регіону до підтримки та розвитку сфери соціального підприємництва. Програма фокусує увагу на необхідності формування сприятливого законодавчого середовища для розвитку соціального підприємництва, популяризації діяльності соціальних підприємств, створення умов для їх фінансування. В Україні соціальне підприємництво по суті немає формального інституціонального визнання. Це впливає й на реалізацію регіональної політики в сфері соціального підприємництва, яка, на думку окремих дослідників, позбавлена системності. Тому пропонується на державному рівні розробити концептуальні засади державної політики розвитку соціального підприємництва. Насамперед, на переконання авторів дослідження, це потрібно для правового чи політичного визнання соціального підприємництва в нашому соціумі [20]. Стратегічною метою державної політики щодо розвитку соціального підприємництва має стати формування умов для вирішення соціальних та екологічних проблем в місцевих громадах завдяки підприємницьким ініціативам.

Тому важливо інтегрувати ідею розвитку соціального підприємництва до регіональних та місцевих програм. Відмітимо, що в ряді регіонів та міст найчастіше порушується питання підтримки та розвитку підприємницьких ініціатив у спеціальних програмах розвитку малого та середнього підприємництва або в складі комплексних програм економічного та соціального розвитку. Що стосується соціального підприємництва, то першість у затвердження такої спеціальної програми належить м. Запоріжжя (2018р.). Її основні завдання спрямовані на визначення переліку найважливіших соціальних проблем міста та соціальних груп мешканців; розвиток співпраці та партнерства між 
Економічні науки: збірник наукових праць Луиького національного технічного університету. Серія "Регіональна економіка". Випуск 17 (67). Редкол.: відп. ред. к.е.н., професор І.В. Кривов'язюк. Луиьк: ІВВ Луцького НТУ, 2020. 348 с.

громадськими організаціями, підприємцями та міською владою; створення в місті осередку, що розвиває та представляє сектор соціального підприємництва; надання консалтингової підтримки соціальним підприємцям; проведення навчальних заходів із питань соціального підприємництва та його популяризація. Також слід відмітити Вінницьку міську ОТГ, програма розвитку соціального підприємництва якої вирізняється структурованістю та комплексністю. Серед основних цілей соціального підприємництва, виділених у програмі, акцентується увага й на необхідності реалізації заходів із охорони навколишнього природного середовища, забезпечення екологічної безпеки, що, на наш погляд, може включати й питання поводження 3 відходами. В інших регіонах країни тематика соціального підприємництва не представлена так широко й виступає складової більш комплексних програм. Щодо соціального підприємництва, там визначені заходи для популяризація ідеї такого підприємництва, моніторингу розвитку цієї сфери (Донецька область, Івано-Франківська область, Київська область, Кіровоградська область, Полтавська область, м. Суми, м. Херсон, м. Рівне, м. Львів). Окремо слід виділити Черкаську область, де в стратегії іiі розвитку визначено необхідність підвищити рівень обізнаності та соціальної активності жителів регіону, для чого пропонується активніше залучати жителів до вирішення місцевих проблем шляхом проведення конкурсів підтримки проєктів розвитку територіальних громад та підтримки інноваційних розробок у сфері утилізації відходів. Програма соціально-економічного та культурного розвитку м. Львів у частині стимулювання сталого економічного розвитку також акцентує увагу на підтримці соціального підприємництва через забезпечення підтримки проєктів, спрямованих на вирішення наявних соціальних проблем, впровадження програми соціальної відповідальності бізнесу, створення клубу соціальних інвесторів задля залучення бізнесу до підтримки соціального підприємництва, а також здійснення підтримки екоініціатив (в місті функціонує соціальне підприємство «Zelenew», яке здійснює переробку пластику). Водночас Львівською 
Економічні науки: збірник наукових праць Луиького національного технічного університету. Серія "Регіональна економіка". Випуск 17 (67). Редкол.: відп. ред. к.е.н., професор І.В. Кривов'язюк. Луиьк: ІВВ Луцького НТУ, 2020. 348 с.

облдержадміністрацією започатковано конкурс із визначення інститутів громадянського суспільства, яким надається фінансова підтримка за рахунок коштів обласного бюджету для створення соціальних підприємств.

Досить часто в аналізованих регіональних програмах стоїть акцент на популяризації соціальної відповідальності бізнесу, відмічається соціальна відповідальність підприємництва. Тут слід розмежовувати питання соціально відповідального бізнесу та соціального підприємництва. Адже, соціальна відповідальність бізнесу визначає рівень відповідальності в поведінці суб' єктів господарської діяльності за їх рішення та дії по відношенню до соціуму та довкілля зокрема. Для більшості представників сучасного бізнесу ця норма поведінки інтегрована у їх діяльність. Хоча питання соціально відповідального бізнесу лежить у площині добровільної діяльності суб'єктів господарювання, але для створення довіри між бізнесом, суспільством i державою, залучення інноваційного потенціалу бізнесу для вирішення завдань сталого розвитку країни в Україні прийнята концепція реалізації державної політики у сфері сприяння розвитку соціально відповідального бізнесу [21]. Одним із напрямів розвитку соціально відповідального бізнесу виступає сфера утилізація відходів, що створює перспективи для міжсекторальної співпраці соціальних підприємців та соціально відповідального бізнесу.

В Україні серед нині існуючих соціальних підприємств мало тих, які займаються сферою поводження з відходами, про що свідчать дані наведені в каталозі соціальних підприємств [22]. Так, можна відлити громадську організацію «Україна без сміття», де пропонуються рішення для роздільного сортування відходів; проєкт «Зелений Птах», що функціонує у формі особистої підприємницької ініціативи й орієнтований на генерування прибутку для фінансування окремих видів послуг, підтримки переробки вторинної сировини не цікавої для основних гравців ринку переробки відходів (паперовий посуд); соціальне підприємство RE:ban, яке просуває культуру 
Економічні науки: збірник наукових праць Луиького національного технічного університету. Серія "Регіональна економіка". Випуск 17 (67). Редкол.: відп. ред. к.е.н., професор І.В. Кривов'язюк. Луиьк: ІВВ Луцького НТУ, 2020. 348 с.

відповідального споживання через повторне використання ресурсів (переробка ПВХ-тканин та ПВХ-сітки, які використовується у виготовленні рекламних банерів на нові продукти); приватне підприємство «ЛавГав», яке працює в особливій сфері побутових відходів - органічні відходи, а саме утилізації продуктів життєдіяльності домашніх тварин (собак).

Як правило підтримка соціального підприємництва в першу чергу асоціюється 3 преференціями в сфері оподаткування. Це пояснюється тим, що соціальні підприємці отримують прибуток, не розраховуючи на благодійну допомогу й вагому частку свого прибутку вони спрямовують на суспільні блага. Тому їм важливі пільги в оподаткуванні прибутку. Власне пільги від діяльності в секторі соціального підприємництва можна отримати правильно обравши організаційно-правову форму функціонування підприємницької структури. Більшість соціальних підприємств в країні функціонують як приватні підприємства, фізичні особи-підприємці. Це дає їм можливість скористатися перевагами спрощеної системи оподаткування. Крім того, соціальним підприємництвом можуть займатися й громадські об'єднання (громадської організації, громадської спілки) відповідно до свого статуту та мети (цілей) громадського об'єднання щодо вирішення соціальних та екологічних проблем. Такі суб'єкти соціального підприємництва вносяться до Реєстру неприбуткових установ та організацій, отже вони не є платниками податку на прибуток підприємств, за умови, що їх прибуток не розподіляється між бенефіціарами

У загальноєвропейській практиці не прийнято встановлювати вагомі податкові пільги для соціальних підприємств. Існують податкові пільги для окремих видів діяльності соціальних підприємств (навчальна та освітня діяльність; розвиток та діяльність, пов'язані 3 інноваціями; надання пожертв у вигляді товарів або послуг певним соціальним групам; працевлаштування осіб у певних населених пунктах із високим рівнем безробіття; інвестиції в малі та середні підприємства; інвестиції в бідні громади). Окрім податкового інструменту, іншими інструментами підтримки 
Економічні науки: збірник наукових праць Луиького національного технічного університету. Серія "Регіональна економіка". Випуск 17 (67). Редкол.: відп. ред. к.е.н., професор І.В. Кривов'язюк. Луиьк: ІВВ Луцького НТУ, 2020. 348 с.

діяльності соціальних підприємств є бізнес-консультації, коучинг, менторський супровід, які враховують різні аспекти діяльності соціальних підприємств; полегшення доступу до ринків збуту товарів або послуг, зокрема ринків державного сектору (ухвалення спеціальних положень у сфері державних закупівель для створення попиту на послуги соціальних підприємств); підтримка доступу до фінансування шляхом створення спеціалізованих фінансових інструментів [23].

Відмітимо, що уряд може надавати регіонам допомогу для забезпечення їх розвитку, фінансувати програми підтримки середнього та малого підприємництва, надавати допомогу для працевлаштування окремих категорій працівників та створення нових робочих місць, підтримувати проведення наукових досліджень та інноваційної діяльності, підтримувати розвиток окремих галузей економіки, що визначено відповідним законом України [24]. Тому на регіональному рівні існуючі програми підтримки малого та середнього підприємництва мають бути скориговані в частині виділення окремої статті для гарантованої фінансової підтримки розвитку соціальних підприємств.

Соціальні підприємці могли б скористатися можливостями фінансування в рамках урядової інвестиційної програми від Українського фонду стартапів, який підтримує інноваційні проєкти. Також привабливою $є$ програма соціального інвестування Western NIS Enterprise Fund орієнтована на забезпечення підтримки приватних підприємств та фізичних осіб-підприємців вирішувати соціальні та екологічні проблеми через фінансові інвестиції та надійні практики ведення бізнесу. Також одним із каналів фінансування може бути державна програма «Доступні кредити 5-7-9 \%».

На наш погляд, слід зміцнювати економічний потенціал соціальних підприємств через розвиток їх кооперації, яка в цій сфері $є$ природньою необхідністю через наявність у секторі цілої когорти дрібних підприємців. Кооперативна модель функціонування соціальних підприємств дозволила б краще здійснювати маркетингові дослідження, покращити можливості отримання технічної допомоги, сприяла б лобіюванню доступу 
Економічні науки: збірник наукових праць Луиького національного технічного університету. Серія "Регіональна економіка". Випуск 17 (67). Редкол.: відп. ред. к.е.н., професор І.В. Кривов'язюк. Луиьк: ІВВ Луцького НТУ, 2020. 348 с.

соціальних підприємців до місцевих ринків продуктів та послуг. Підприємці можуть розвивати як вертикальну, так i горизонтальну форми кооперації, адже вони мають різні функціональні обов'язки в системі поводження 3 відходами. Одні можуть обслуговувати весь цикл системи, інші - окремі його стадії (заготівля і постачання, переробка, виробництво продукту). Рзвиток таких кооперативів дозволить налагодити співпрацю з переробним бізнесом у сфері відходів.

Висновки. На наше переконання вирішення проблеми рециркуляції відходів, раціонального використання ресурсів можливе за умови підтримки розвитку соціального підприємництва, яке може стати каталізатором упровадження моделі кругової економіки завдяки посиленню спроможності та згуртованості місцевих громад. Соціальне підприємництво дозволяє змінити звичні стереотипи поведінки громадян у контексті підвищення їх відповідальності та готовності свідомо перейняти практики поводження 3 відходами на принципових засадах кругової економіки. Соціальне підприємництво сприяє інклюзії та публічності, дозволяє залучити членів громади до праці на досягнення спільного блага - вирішення проблеми накопичення та переробки відходів й створення на основі цього доданої вартості. Соціальне підприємництво для моделі кругової економіки цікаве й тим, що тут не акцентується увага на розподілі прибутку між бенефіціарами, адже реінвестується для досягнення цілей переробки відходів, відновлення ресурсів. Таким чином, й кругова економіка, й соціальне підприємництво мають схожу природу - циклічну. Ідея використати інструмент соціального підприємництва для переходу на модель кругової економіки в сфері поводження 3 побутовими відходами має перспективу, а сам цей інститут потребує найскорішого визнання та застосування в регіональній економічній політиці.

\section{Список бібліографічного опису}

1. Murray A., Skene K., Haynes K. The Circular Economy: An Interdisciplinary Exploration of the Concept and Application in a Global Context. Journal of Business Ethics. 2017. Volume 140. Issue 3. Pp. 369-380. URL: https://link.springer.com/content/pdf/10.1007\%2Fs10551-015-2693-2.pdf (дата звернення: 09.08.2019). 
Економічні науки: збірник наукових праць Луиького національного технічного університету. Серія "Регіональна економіка". Випуск 17 (67). Редкол.: відп. ред. к.е.н., професор І.В. Кривов’язюк. Луцьк: ІВВ Луцького НТУ, 2020. 348 с.

2. Millar N., McLaughlin E., Börger T. The Circular Economy: Swings and Roundabouts. Discussion papers in Environmental Economics. University of St. Andrews. 2019. 26 p. URL: https://www.st-andrews.ac.uk/media/dept-ofgeography-and-sustainable-development/pdf-s/DP\%202019-

01\%20Millar\%20et\%20al.pdf (дата звернення: 11.01.2020).

3. Waste Management in Europe. Good Jobs in the Circular Economy? / Steve Thomas, Jane Lethbridge, Emanuele Lobina, David Hall, Jeff Powell, Sandra Van Niekerk, Vera Weghmann, Yuliya Yurchenko. 2017. 45 p. URL: https://www.epsu.org/sites/default/files/article/files/Waste\%20Management\%20in\% 20Europe.\%20Good\%20Jobs\%20in\%20the\%20Circular\%20Economy\%20for\%20w eb.pdf (дата звернення 23.03.2020).

4. Савченко Н. Циркулярна економіка як світовий тренд: вплив на державну політику зайнятості населення. Актуальні проблеми державного управління. 2018. № 2. С. 109-113.

5. Зварич І.Я. Циркулярна економіка і глобалізоване управління відходами. Журнал європейської економіки. 2017. № 1. Т. 16. С. 41-57.

6. Бойченко С.Г. Особливості соціального підприємництва в Україні. Modern technology, business and law: collection of internatonal scientific papers: in 2 parts. Chernihiv. 2016. № 1. C. 18-20.

7. Доброва Н.В. Соціальне підприємництво. Економічні інновації. 2015. № 59. С. 112-117.

8. Чуйко О., Шкуро В. Еколого орієнтоване соціальне підприємництво у громаді : навч.-метод. посіб. Київ, 2020. 124 с.

9. Статистичний збірник «Довкілля України за 2016 рік» / За ред. О. М. Прокопенко. Київ : Державна служба статистики України, 2017. 226 с. URL: http://www.ukrstat.gov.ua/ (дата звернення: 17.03.2020).

10. Статистичний збірник «Довкілля України за 2018 рік» / За ред. О. М. Прокопенко. Київ : Державна служба статистики України, 2019. 214 с. URL: http://www.ukrstat.gov.ua/druk/publicat/kat_u/2019/zb/11/Zb_dovk_2018.pdf (дата звернення: 17.03.2020).

11. Generation of waste by waste category, hazardousness and NACE Rev. 2 activity. Eurostat, 2020. URL: http://appsso.eurostat.ec.europa.eu/nui/show.do (дата звернення: 17.03.2020).

12. $492 \mathrm{~kg}$ of municipal waste generated per person in the EU / Products Eurostat News. Eurostat, 2020. URL: https://ec.europa.eu/eurostat/web/productseurostat-news/-/DDN-20200318-1 (дата звернення: 18.03.2020).

13. Стан сфери поводження з побутовими відходами в Україні за 2019 рік. Міністерство розвитку громад та територій України, 2020. URL: https://www.minregion.gov.ua/napryamki-diyalnosti/zhkh/terretory/stan-sferypovodzhennya-z-pobutovymy-vi/ (дата звернення: 18.03.2020).

14. Стан сфери поводження з побутовими відходами в Україні за 2018 рік. Міністерство розвитку громад та територій України, 2019. URL: https:/www.minregion.gov.ua/napryamki-diyalnosti/zhkh/terretory/stan-sferipovodzhennya-z-pobutovimi-vidhodami-v-ukrayini-za-2018-rik/ (дата звернення: 18.03.2020). 
Економічні науки: збірник наукових праць Луиького національного технічного університету. Серія "Регіональна економіка". Випуск 17 (67). Редкол.: відп. ред. к.е.н., професор І.В. Кривов’язюк. Луцьк: ІВВ Луцького НТУ, 2020. 348 с.

15. Стан сфери поводження з побутовими відходами в Україні за 2017 рік. Міністерство розвитку громад та територій України, 2018. URL: https://www.minregion.gov.ua/napryamki-diyalnosti/zhkh/terretory/stan-sferipovodzhennya-z-pobutovimi-vidhodami-v-ukrayini-za-2017-rik/ (дата звернення: 18.03.2020).

16. Стан сфери поводження з побутовими відходами в Україні за 2016 рік. Міністерство розвитку громад та територій України, 2017. URL: https://www.minregion.gov.ua/napryamki-diyalnosti/zhkh/terretory/stan-sferipovodzhennya-z-pobutovimi-vidhodami-v-ukrayini-za-2016-rik/ (дата звернення: 18.03.2020).

17. Стан сфери поводження з побутовими відходами в Україні за 2015 рік. Міністерство розвитку громад та територій України, 2016. URL: https:/www.minregion.gov.ua/napryamki-diyalnosti/zhkh/terretory/stan-sferipovodzhennya-z-pobutovimi-vidhodami-v-ukrayini-za-2015-rik/ (дата звернення: 18.03.2020).

18. Статистичний збірник «Регіони України» 2019 / За ред. I.Є. Вернера. Ч.І. Київ : Державна служба статистики України, 2019. 309 с. URL: http://www.ukrstat.gov.ua/druk/publicat/kat_u/2019/zb/12/zb_ru1ch2019.pdf (дата звернення: 18.03.2020).

19. Чисельність населення (за оцінкою) на 1 січня 2020 року та середня чисельність у 2019 році. Державна служба статистики України, 2020. URL: http://www.ukrstat.gov.ua/ (дата звернення: 18.03.2020).

20. Кокоть В., Регелюк С., Бочарнікова А. Розвиток соціального підприємництва в Україні. Біла книга. Київ, 2020. 113 с.

21. Про схвалення Концепції реалізації державної політики у сфері сприяння розвитку соціально відповідального бізнесу в Україні на період до 2030 року : Розпорядження Кабінету Міністрів України від 24.01.2020 р. № 66p. URL: https://zakon.rada.gov.ua/laws/show/66-2020-\%D1\%80\#Text (дата звернення: 02.04.2020).

22. Каталог соціальних підприємств України 2016-2017 рр. Довідкове видання. Київ, 2017. 300 с.

23. A Map of Social Enterprises and their Eco-systems in Europe: Synthesis Report / European Commission, Directorate-General for Employment, Social $\mathrm{A} \square$ airs and Inclusion. 2015. 142 p. URL: https://ec.europa.eu/social/BlobServlet?docId=12987\&langId=en (дата звернення 27.04.2019).

24. Про державну допомогу суб'єктам господарювання : Закон України від 01.07.2014 р. № 1555-VII. Дата оновлення: 16.07.2020. Відомості Верховної $Р a \partial u$. 2014. № 34. C.1173. URL: https://zakon.rada.gov.ua/laws/show/155518\#Техt (дата звернення: 16.08.2020).

\section{References}

1. Murray A., Skene K., Haynes K. The Circular Economy: An Interdisciplinary Exploration of the Concept and Application in a Global Context. Journal of Business Ethics, 2017, vol. 140, issue 3, pp. 369-380. Available at: 
Економічні науки: збірник наукових праць Луиького національного технічного університету. Серія "Регіональна економіка". Випуск 17 (67). Редкол.: відп. ред. к.е.н., професор І.В. Кривов’язюк. Луцьк: ІВВ Луцького НТУ, 2020. 348 с.

https://link.springer.com/content/pdf/10.1007\%2Fs10551-015-2693-2.pdf (accessed 09.08.2019).

2. Millar N., McLaughlin E., Börger T. The Circular Economy: Swings and Roundabouts. Discussion papers in Environmental Economics, University of St. Andrews, 2019, 26 p. Available at: https:/www.st-andrews.ac.uk/media/dept-ofgeography-and-sustainable-development/pdf-s/DP\%202019-

01\%20Millar\%20et\%20al.pdf (accessed 11.01.2020).

3. Steve Thomas, Jane Lethbridge, Emanuele Lobina, David Hall, Jeff Powell, Sandra Van Niekerk, Vera Weghmann, Yuliya Yurchenko.Waste Management in Europe. Good Jobs in the Circular Economy? 2017, 45 p. Available at:

https://www.epsu.org/sites/default/files/article/files/Waste\%20Management\%20in\% 20Europe. $\% 20$ Good $\% 20$ Jobs $\% 20$ in $\% 20$ the $\% 20$ Circular\%20Economy $\% 20$ for $\% 20 \mathrm{w}$ eb.pdf (accessed 23.03.2020).

4. Savchenko N. Tsyrkulyarna ekonomika yak svitovyy trend: vplyv na derzhavnu polityku zaynyatosti naselennya. Aktual'ni problemy derzhavnoho upravlinnya, 2018, no 2, pp. 109-113 [in Ukrainian].

5. Zvarych I. Ya. Tsyrkulyarna ekonomika i hlobalizovane upravlinnya vidkhodamy. Zhurnal yevropeys'koyi ekonomiky, 2017, no 1, vol. 16, pp. 41-57 [in Ukrainian].

6. Boychenko S. H. Osoblyvosti sotsial'noho pidpryyemnytstva v Ukrayini. Modern technology, business and law: collection of internatonal scientific papers: in 2 parts. Chernihiv, 2016, no 1, pp. 18-20 [in Ukrainian].

7. Dobrova N. V. Sotsial'ne pidpryyemnytstvo. Ekonomichni innovatsiyi, 2015, no 59, pp. 112-117 [in Ukrainian].

8. Chuyko O., Shkuro V. Ekoloho oriyentovane sotsial'ne pidpryyemnytstvo u hromadi : navch.-metod. posib. Kyyiv, 2020, 124 p. [in Ukrainian].

9. Statystychnyy zbirnyk «Dovkillya Ukrayiny za 2016 rik» / Za red. O. M. Prokopenko. Kyyiv, Derzhavna sluzhba statystyky Ukrayiny, 2017, 226 p. Available at: http://www.ukrstat.gov.ua/ (accessed 17.03.2020). [in Ukrainian].

10. Statystychnyy zbirnyk «Dovkillya Ukrayiny za 2018 rik» / Za red. O. M. Prokopenko. Kyyiv, Derzhavna sluzhba statystyky Ukrayiny, 2019, 214 p. Available http://www.ukrstat.gov.ua/druk/publicat/kat_u/2019/zb/11/Zb_dovk_2018.pdf (accessed 17.03.2020) [in Ukrainian].

11. Generation of waste by waste category, hazardousness and NACE Rev. 2 activity. Eurostat, 2020. Available at: http://appsso.eurostat.ec.europa.eu/nui/show.do (accessed 17.03.2020).

12. $492 \mathrm{~kg}$ of municipal waste generated per person in the EU / Products Eurostat News. $\quad$ Eurostat, Available at: https://ec.europa.eu/eurostat/web/products-eurostat-news/-/DDN-20200318-1 (accessed 18.03.2020).

13. Stan sfery povodzhennya z pobutovymy vidkhodamy v Ukrayini za 2019 rik. Ministerstvo rozvytku hromad ta terytoriy Ukrayiny, 2020. Available 
Економічні науки: збірник наукових праць Луиького національного технічного університету. Серія "Регіональна економіка". Випуск 17 (67). Редкол.: відп. ред. к.е.н., професор І.В. Кривов’язюк. Луцьк: ІВВ Луцького НТУ, 2020. 348 с.

at:https://www.minregion.gov.ua/napryamki-diyalnosti/zhkh/terretory/stan-sferypovodzhennya-z-pobutovymy-vi/ (accessed 18.03.2020). [in Ukrainian].

14. Stan sfery povodzhennya z pobutovymy vidkhodamy v Ukrayini za 2018 rik. Ministerstvo rozvytku hromad ta terytoriy Ukrayiny, 2019. Available at: https:/www.minregion.gov.ua/napryamki-diyalnosti/zhkh/terretory/stan-sferipovodzhennya-z-pobutovimi-vidhodami-v-ukrayini-za-2018-rik/

(accessed 18.03.2020) [in Ukrainian].

15. Stan sfery povodzhennya z pobutovymy vidkhodamy v Ukrayini za 2017 rik. Ministerstvo rozvytku hromad ta terytoriy Ukrayiny, 2018. Available at: https://www.minregion.gov.ua/napryamki-diyalnosti/zhkh/terretory/stan-sferipovodzhennya-z-pobutovimi-vidhodami-v-ukrayini-za-2017-rik/ (accessed 18.03.2020) [in Ukrainian].

16. Stan sfery povodzhennya z pobutovymy vidkhodamy v Ukrayini za 2016 rik. Ministerstvo rozvytku hromad ta terytoriy Ukrayiny, 2017. Available at: https://www.minregion.gov.ua/napryamki-diyalnosti/zhkh/terretory/stan-sferipovodzhennya-z-pobutovimi-vidhodami-v-ukrayini-za-2016-rik/ (accessed 18.03.2020) [in Ukrainian].

17. Stan sfery povodzhennya z pobutovymy vidkhodamy v Ukrayini za 2015 rik. Ministerstvo rozvytku hromad ta terytoriy Ukrayiny, 2016. Available at: https://www.minregion.gov.ua/napryamki-diyalnosti/zhkh/terretory/stan-sferipovodzhennya-z-pobutovimi-vidhodami-v-ukrayini-za-2015-rik/ (accessed 18.03.2020) [in Ukrainian].

18. Statystychnyy zbirnyk «Rehiony Ukrayiny» 2019 / Za red. I.Ye. Vernera. Ch. I. Kyyiv, Derzhavna sluzhba statystyky Ukrayiny, 2019, 309 p. Available at: http://www.ukrstat.gov.ua/druk/publicat/kat_u/2019/zb/12/zb_ru1ch2019.pdf (accessed 18.03.2020) [in Ukrainian].

19. Chysel'nist' naselennya (za otsinkoyu) na 1 sichnya 2020 roku ta serednya chysel'nist' u 2019 rotsi. Derzhavna sluzhba statystyky Ukrayiny, 2020. Available at:http://www.ukrstat.gov.ua/ (accessed 18.03.2020) [in Ukrainian].

20. Kokot' V., Rehelyuk S., Bocharnikova A. Rozvytok sotsial'noho pidpryyemnytstva v Ukrayini. Bila knyha. Kyyiv, 2020, 113 p. [in Ukrainian].

21. Pro skhvalennya Kontseptsiyi realizatsiyi derzhavnoyi polityky u sferi spryyannya rozvytku sotsial'no vidpovidal'noho biznesu v Ukrayini na period do 2030 roku. Rozporyadzhennya Kabinetu Ministriv Ukrayiny vid 24.01.2020 r, no 66-r. Available at: https://zakon.rada.gov.ua/laws/show/66-2020-\%D1\%80\#Text (accessed 02.04.2020) [in Ukrainian].

22. Kataloh sotsial'nykh pidpryyemstv Ukrayiny 2016-2017 rr. Dovidkove vydannya. Kyyiv, 2017, 300 p. [in Ukrainian].

23. A Map of Social Enterprises and their Eco-systems in Europe: Synthesis Report / European Commission, Directorate-General for Employment, Social $\mathrm{A} \square$ airs and Inclusion, 2015, 142 p. Available at: https://ec.europa.eu/social/BlobServlet?docId=12987\&langId=en (accessed 27.04.2019). 
Економічні науки: збірник наукових праць Луиького начіонального технічного університету. Серія "Регіональна економіка". Випуск 17 (67). Редкол.: відп. ред. к.е.н., професор І.В. Кривов’язюк. Луцьк: ІВВ Луцького НТУ, 2020. 348 с.

24. Pro derzhavnu dopomohu sub"yektam hospodaryuvannya : Zakon Ukrayiny vid 01.07.2014 r. \# 1555-VII. Data onovlennya: 16.07.2020. Vidomosti Verkhovnoyi Rady, 2014, no 34, p.1173. Available at: https://zakon.rada.gov.ua/laws/show/1555-18\#Text (accessed 16.08.2020) [in Ukrainian]. 